\title{
Study of Effective Land Registration Usage in State-Subsidised Housing
}

\author{
Michael Barry and Lani Roux \\ Geomatics Engineering Department, University of Calgary, Canada, mbarry@ucalgary.ca
}

\section{DOI: http://dx.doi.org/10.4314/sajg.v5i1.6}

\begin{abstract}
Project II is the third case study to be reported on land tenure administration in statesubsidised housing projects the Western Cape which indicate that registration is effective in administering ownership. Internationally, many land titling programmes have not produced the benefits envisaged. In a number of South African state-subsidised housing projects a number of houses have changed hands off-register, which creates costly long-term land tenure administration problems. The Project II study examined the strategies that people use to defend their tenure and to effect transactions in land. While there are major problem cases in South Africa, the Project II study, building on two similar case studies, indicates that individual tenure, registered in ownership, can work in pro-poor housing programmes if the right conditions exist. Although there was evidence of off-register transactions in all three case studies, the situation can be improved by hands on management to create and maintain the enabling conditions for registration to be effective rather than major changes in law, policy and land administration practice. Distinctive, new knowledge, emerging from Project II is how an iconic "bad news" event can influence local knowledge and behaviour.
\end{abstract}

\section{Introduction}

The paper examines the effectiveness of official land tenure administration systems, and landholders' perceptions of these systems in Project II, a state-subsidised housing project on Avondale. It builds on findings from two comparable studies, Projects $A \& B$ and Drakenstein-97 (Barry and Roux 2014, 2016). Avondale is a former so-called coloured suburb in a coastal town $130 \mathrm{~km}$ from Cape Town. Projects $A \& B$ and Drakenstein-97 are also in historically coloured suburbs in two other Western Cape towns. Note that Avondale, Projects A \& B and Drakenstein-97 are pseudonyms for ethical reasons.

South African government statistics indicate that 2.8 million housing units and 900,000 serviced sites have been made available through state programmes since 1994 (Department of Human Settlements 2014). There is, however, a significant backlog in registering state-subsidised housing units. Further, a number of reports show that many of the registered units have been transferred off-register, and so the titles are cloudy (Gordon et al 2011, Financial and Fiscal Commission 2012). Cloudy titles remove the affected properties from the formal land market, 
making it expensive and extremely challenging to clean up the titles (Downie 2011). Cloudy titles also add to the administrative burdens on the land taxation and municipal services systems as officials have to work with inaccurate records. Whereas there are major problems in some housing projects, the Project II, Projects A \& B and Drakenstein-97 cases indicate that ownership can be made to work in state-subsidised housing projects in South Africa.

In the international context, the study adds to the small body of empirical work that explicitly examines how landholders perceive and use land tenure administration instruments and processes. Internationally, there is a need for theory related to effective land tenure administration that has a strong empirical base. There are considerable problems in administering land tenure equitably, especially for the less-powerful. One expert's guesstimate is that only $25 \%$ of parcels worldwide are registered (McLaren 2012). Land titling has been a principal strategy in poverty alleviation and economic development strategies since World War II, frequently based on the hypothesis that individual private property supported by registered titles is lead to secure tenure and create wealth. However, it is well documented that in many projects the results have been poor. In addition to impacting cloudy titles impacting municipal service provision and land taxation, negative outcomes include elites using land titling as a system to extinguish land interests and for outright land grabbing (Shipton 2009). Alternatives to ownership and individual titles, such as the continuum of land rights metaphor and the social tenure domain model have been proposed to address these issues (UN-Habitat /GLTN 2012, Barry 2015). However, these proposed alternatives carry similar risks of the negative consequences of titling if the right conditions for them to function do not exist. The questions then are what are the conditions in different scenarios and can they be created and maintained?

Project II is one of a set of studies that the authors have conducted / are conducting concerning land tenure administration institutions, instruments and processes in South Africa, Ghana, Somaliland, Nigeria and Kenya. The focus is on the strategies that people actually use or intend to use to secure their interests in land, plus their perceptions of official land tenure administration systems, i.e. the artifacts, institutions and processes that constitute these systems.

The paper proceeds by describing the theory building approach which has guided a number of case studies, followed by the methodology used in Project II, the Projects $A \& B$, and Drakenstein-97 cases. A summary of the general findings from the Projects $A \& B$ and Drakenstein-97 cases are then presented, followed by a brief history of Avondale and a description and analysis of the Project II study.

\section{Theory Building Approach}

The theory building approach used in the three case studies is described in detail in Barry and Roux $(2012$, 2013). The case studies are part of a broader research programme which examines a particular theory about land tenure form and land tenure support system fit during different levels of change ranging from stable to far reaching as conceptualised in figure 1. As an example of a 
changing situation where such a theory might be tested, South Africa's state-subsidised housing programme was initiated during significant change in the 1990's as the country navigated through a comparatively peaceful post-conflict situation. Today, the situation might be classified as being in a period of mild change in the context of housing supply. A social theory is likely to be valid under certain conditions and invalid when another set of conditions are present. An example of a condition set might be: (1) homeowners are middle class, (2) they are employed, and (3) they can afford to service a mortgage. While case studies tend to generate detailed, rich, substantive level explanatory theory that might inform corrective action at the local level, the emphasis in this article is on extracting general patterns. General theory informs the design of policy, law and the operations management function in land tenure administration. Figure 1 is a way of communicating to policy makers and politicians how a particular theory has been shown to work or not work under different conditions during different types of change. Theory in this context is a set of hypotheses, each of which are valid under a particular set of conditions.

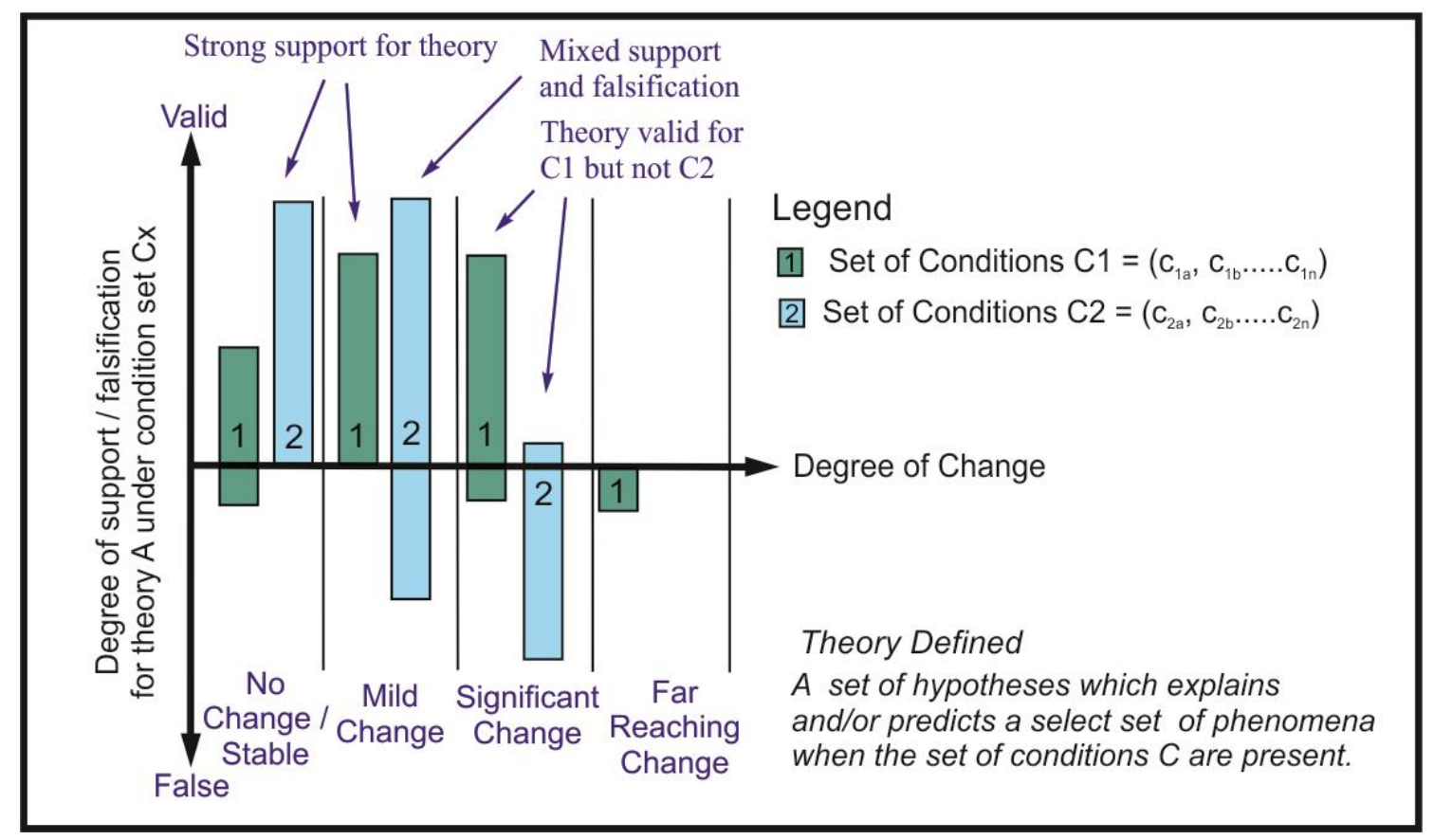

Figure 1. Empirical Support for a particular Land Tenure Type - Tenure Support System Theory under different sets of conditions.

Figure 1 portrays, in concept, the weight of evidence which supports or falsifies a particular theory under given sets of conditions (e.g. C1 and C2) during different types of change. Case studies where similar conditions exist can be studied to generate hypotheses concerning the tenure form - land system fit under that condition set in a particular level of social, political and economic change. Empirical support for a theory is built as each new case study is added, and the level of support might be assessed in terms of the number and quality of the studies where those conditions 
exist. Hypotheses can be compared from case to case, and validated, falsified, or modified as more research is conducted. If there is strong support for a theory with little or no evidence showing parts of it to be false under particular sets of conditions, then it may be a useful input into the design of policy and practice. If mixed results indicating support for and falsification of the theory emerge in different case studies, then the theory, the set of conditions, or both are ill-defined and they should be reformulated. If a number of studies indicate that the theory is false and perhaps a small weight of evidence supports it, then obviously that theory should not be the basis of policy and practice under those conditions. This is the major problem associated with the 'land titling generates economic benefits for the poor' theory mentioned above. It is valid under certain conditions and is likely to lead to the benefits envisaged under those conditions. It can do damage when those conditions, the critical success factors, are not present. Even if they are present land titling may not work during a particular level of change, hence a theory may be valid under certain conditions in a stable situation but completely inappropriate during significant change when the same conditions are present.

A caution is that figure 1 should not be applied mechanistically. It can be used to present the results of indicators based on quantitative estimates if there are sufficient reliable data. More likely it will serve as a tool to discuss and debate different theories about land tenure form and how that form might be administered and the empirical basis for those theories when formulating policy and practice.

\section{Methodology}

The Drakenstein-97, Projects A \& B and Project II cases occurred in a relatively stable environment. The benefits of studying pro-poor land tenure administration programmes in stable situations is that they show what conditions are present and/or need to be created when a system works well. When problems abound and the environment is fragile and perhaps conflict ridden there is a temptation to focus on problematic cases in the hope of "fixing" them, perhaps introducing grand scale changes. Instead, incremental changes to existing tenure administration systems may well yield better results. The set of conditions common to these cases are:

(1) The studies are in state-subsidised housing projects in former coloured areas (a legacy of apartheid era group areas definitions) in three Western Cape towns. The majority of original housing beneficiaries have lived in the area for a long time, and therefore should have experience or hearsay knowledge of using official land administration systems. They are not in-migrants from places where different laws, social processes and official procedures are used in land tenure administration. In-migrants, such as people from a rural customary area, or immigrants from another country may apply land tenure administration practices from their place of origin in their "new" place. From an official perspective, these practices may cause problems in the "new" place. 
(2) Overall, the different state agencies, the municipality, the provincial authorities, the Deeds Office and the Surveyor-General's office and the land professionals had been efficient in delivering the houses, managing the subsidies, preparing the documents, and getting the properties registered during a time of far reaching change. No concrete evidence of corruption or abuse of power emerged.

(3) Ongoing conflict and competition over power and access to housing in local level politics, perhaps involving a number of non-government institutions and perhaps local level warlords, were absent. Consequently, the housing projects were not disrupted and delayed by invasions of empty houses

The Project II study comprised 62 qualitative interviews in a housing estate that now comprises 253 houses. Sixteen key-informants included four people directly involved with Project $I I$, and the remaining 12 were involved with numerous housing projects in the municipal area. Keyinformants included local politicians, lawyers, municipal officials, bank officials, business owners and land surveyors. Using purposive sampling, 46 door-to-door interviews were conducted with 52 residents. Nine of these interviews were with people who had bought a house or were in the process of buying a house. Thirty six interviews were with original beneficiaries, of whom five had been assisted in obtaining a house by their employer, a local winery, and the remainder had received state subsidies. One participant inherited a house from an original beneficiary. Thirty interviews involved people who had lived in Avondale or a nearby town all their lives. The rest had moved from farms and towns nearby and some from further afield in the Western Cape. Documentary evidence included council minutes, local newspaper archives stretching back to the project planning phase and beyond, census data, title deeds and other documents given to the authors in the field, and deeds registry transaction data from the inception of the project. There is hearsay evidence that foreigners, immigrants from other African countries such as Nigeria and Somalia, had bought houses off-register. Due to the sensitivity of xenophobic attacks on foreigners (the authors witnessed such an attack), it was difficult to explore the issue. Immigrants who were approached refused an interview.

Residents were asked about their life histories, how they acquired their house and their knowledge of success stories (i.e. what is working well in the neighbourhood) and problem cases in land tenure administration in the neighbourhood. The study also examined the strategies that they might use, had used, or had observed others in the neighbourhood using to defend their tenure if threatened with eviction, and the strategies they might employ if they wished to sell their house. These parts of the interviews revealed the importance of documents such as title deeds, the importance of the role of lawyers in land tenure management, and the level of trust in the municipality.

The general findings from the Projects $A \& B$ and Drakenstein-97 case studies are reported first, and then the results of Project II are presented and compared. The Projects $A \& B$ study 
included 36 door to door interviews with residents and 18 key-informant interviews. The Drakenstein-97 study included 45 resident and 21 key-informant interviews (Barry and Roux 2014, 2016). The key-informant profiles and types of documentary evidence were the same as those in Project II.

\section{Projects A \& B and Drakenstein-97 Findings}

General patterns that emerged from the Projects $A \& B$ and Drakenstein-97 studies are as follows. The first is that security of tenure is of major importance to the original beneficiaries who are still in their houses and to the many people who have bought houses in these housing projects from beneficiaries. They can be expected to use the most effective strategies available to them, official or otherwise, to secure their tenure and secure transactions. Whereas a small number of beneficiaries in both cases sold soon after they received their houses, the remaining beneficiaries and buyers indicated that having a house of their own had made a major difference to their lives. Accommodation is in short supply, many had experienced forced removals during the apartheid era, and having a home for the family is very important (Barry and Roux 2014, 2016).

In general, beneficiaries and registered buyers of state-subsidised houses considered statebased land tenure administration to be legitimate and the primary means by which they would choose to secure their tenure. They believed paper documents, title deeds and other official documents (e.g. municipal accounts), to be legitimate and effective. If they feared that they might lose their home, with a few exceptions, homeowners would approach lawyers and/or the local municipality. The legitimacy, the usefulness, of these instruments and institutions are critical in any effective land tenure administration system. With the exception of a few people who had been involved in off-register transactions, participants did not intend to use alternative structures such as street committees or social processes such as neighbours-as-witnesses to handle land transactions or to assist if there were threats to their land interests. While some homeowners expressed a general distrust of the municipality, and a smaller number expressed a distrust of lawyers, they still expressed a sufficient level of trust to approach a lawyer or a state institution if they had a problem with their home ownership. There were no other tenure administration institutions, such as street committees, available to landholders, but they had also not attempted to create them. What did not emerge were widespread beliefs that official administration organisations, such as the municipality, are corrupt. In both of these cases the municipality, the land professionals and the construction company that built the houses appeared to have acted efficiently throughout the project. A small number of people who had fallen into debt on their municipal account feared that they might lose the house because of unpaid debt, but not through sharp practice or fraud by officials or politically connected individuals (Barry and Roux 2014, 2016).

Fraud and sharp practice involving elites and officials can be a major influence in some communities and create a climate of fear and conflict (Barry and Danso 2014). Participants had learned through the media and local hearsay about how people had sold a house off-register and 
then reclaimed it. Acquiring knowledge through newsworthy stories is one variable that appeared to play a role in strengthening a positive attitude, or at least a neutral attitude, towards official institutions with regard to land tenure administration. Thus homeowners indicated that they would use official institutions and, with the exception of a small number who had purchased off-register, had used them. In Drakenstein-97, mirroring stories in other case studies, one resident told of how she was one of a number of beneficiaries whose homes had been invaded by people attempting to jump the housing waiting list before they could move in. She was forced to wait for the law to take its course and for the invaders to be evicted (Barry and Roux 2014).

Accurate estimates of off-register transactions are not easily measured. The buyers often refuse to be interviewed. Although the vast majority of participants indicated that they would use official systems, persuasive evidence of up to six off-register transactions emerged in Drakenstein97. It was possible to interview occupants in two of these households, but they were elusive in describing how they had acquired their houses. Three people who had been involved in off-register transactions were interviewed in Projects $A \& B$, and it was clear that more had occurred in that project. Key informants suggested that most off-register transactions occur through lack of knowledge (Int \#152); the same informant also reported this to Vorster and Tolkien (2009) who make the same claim. Lack of knowledge explains some off-register transactions. In one of the three off-register interviews in Projects $A \& B$, the buyer purchased off-register, but then on the advice of family and friends approached a lawyer who then had the transaction registered. In another, Somali immigrant A, sold off-register to Somali immigrant B, who then sold to interviewee $\mathrm{C}$. In the transaction between $\mathrm{A}$ and $\mathrm{B}$, the two parties to the transaction became aware of the legal processes and a lawyer organised a tripod transfer from A to B to C. Fortunately the original seller A could be traced, and so the documents necessary for registration could be signed. In a third case the buyer had obtained a loan from her employer and the title deed and cash price were handed over in front of witnesses and the municipal account was transferred to the buyer's name. It appears unusual for the employer to support an off-register transaction, as the employer is a home owner could not have been ignorant of the legal requirements in buying and selling land. That said, the first author has encountered one other case where a corporate employer supported employees in purchasing houses off-register (Barry and Roux 2016).

In general, key-informants indicated that people sell off-register because of financial distress (loss of job, medical expenses) or a need to move towns or to retire to a home in a former customary area. There is evidence from case studies in Cape Town at the inception of the housing projects, and in the Drakenstein-97 case, of local level money lenders and drug dealers taking over houses in lieu of debt (Barry 1999, 2006, Barry and Roux 2014). Key informants and some participants in the field indicated that off-register cases involve a seller who was indebted to a local shebeen owner (informal bar) or drug-dealer (Barry 1999, Barry and Roux 2014). In the Drakenstein-97 case (Barry and Roux 2014), in Roux (2013) and in (Downie (2011), stories 
emerged of a seller taking the money and then disappearing, perhaps returning to a rural village where they could not be traced.

A further possible cause of off-register transactions is intestate succession and the surviving family not following the legal route in managing the estate. There is a history of cases going back to the $19^{\text {th }}$ century and ongoing evidence of dead man's titles in parts of South Africa where heirs have not registered land that that they have inherited (Greene 1994, Kingwill 2013). In spite of people supposedly being informed of the need to have a will through various formal and informal education initiatives, persuasive evidence emerged that many of them did not have one. The consequence is that the heirs may not register the transaction involving the inheritance of the property and so a "dead man's title" may result. It is difficult to acquire compelling evidence in a study as questions about land tenure can be a sensitive matter, especially since some of the participants had been victims of forced removals during the apartheid era, and incorporating questions about inheritance on top of that may distress participants. However, the Drakenstein-97 and Projects $A \& B$ case studies did raise a flag that off-register inheritance of property might occur (Barry and Roux 2014, 2016).

Thus based on previous work in studies with similar conditions and a similar ethnographic profile, the Project II study could be expected to show that the registration of ownership is a workable tenure form and it can be made to work with some minor interventions. A small number of off-register transactions may occur, and there are concerns that these might increase when the original beneficiaries' properties are inherited (Barry and Roux 2014, 2016).

\section{Avondale}

Project II is in Avondale, which was established circa 1930 (Local newspaper 08/04/2005). It was formally declared a coloured group area in 1978, but coloured people who lived in the surrounding urban areas were forced to move to Avondale in terms of the Group Areas Act as far back as 1961. In 1965 black Africans in Avondale were moved to a declared black group area nearby (6 Interviews; Local Newspapers 1965 - 1999; Surveyor General Noting Sheets).

In general, people in Avondale have a history of using state land tenure administration systems. Prior to 1978 all the houses in Avondale were municipal rental houses. From 1984 tenants were able to buy their rental homes, and in 1989 a hire-purchase scheme which the municipality administered was initiated. In all of these sales, a title restriction preventing the sale of the house for five years served as a forerunner to the eight year restriction on selling state-subsidised houses currently in the Housing Act 107 of 1997, s.10a and s.10b (Local Newspapers 1976- 1990). Important issues that the municipality administered were inheritances and transfers of leases and hire purchase houses because the lessee or purchaser could not afford to keep up with monthly payments. Council minutes spanning the 1990's reveal a number of requests to transfer rental properties and to transfer owned properties within the five year restriction. The minutes also show 
that the municipality was careful to take into account the interests of spouses, children and elderly household members when considering these applications.

\section{Project II}

Project II is the second phase of a state-subsidised housing project on Avondale which started in 1998. Beneficiaries were granted full ownership. The original deeds included a restrictive condition prohibiting owners from selling within five years without permission from the municipality (Local Newspapers 11/7/1997, 10/10/1997, Council minutes 27/7/1999). This is one condition that applies to Project II which did not apply in Drakenstein-97 and Projects A \& B title deeds. The clause was the brainchild of a social compact committee formed in 1995. The committee included representatives from the Avondale community, political parties, sports clubs, churches, schools, the municipality and the housing developer (Social Compact minutes 27/11/1995, Council minutes 13/02/1996, 30/04/1996, 24/06/1997). A similar title condition had existed in hire-purchase arrangements in the 1980's where tenants could purchase their houses over time. The rationale was that new homeowners might sell their houses immediately after getting ownership and also sell the houses for much less than their cost replacement value. In turn these sales might lead to an increase in informal settlements, as people might sell and then go and "squat" again. Also, the Council wanted to protect itself against supporting "reckless sales or speculation". The council had topped up the national government housing subsidy by R4,200 and had to show that the expenditure was prudent (Council Minutes 27/07/ 1999). Project II has not been beset by delays in registration that have beleaguered many other state-subsidised housing projects in South Africa, and so the land tenure administration problems distinctive to those projects are absent. Project II transfers started in 1999 and by the end of 2001, 226 deeds, the majority of the houses completed at that time, had been transferred to the beneficiaries (Council minutes 27/07/1999, Deeds Office Transfer records).

\subsection{Tenure Securing Strategies}

In harmony with Projects 97 and A \& B, door to door interviews revealed that having a home of their own has made a major difference in the lives of both original beneficiaries and buyers. It is therefore a rational expectation that they will use the most effective system available to them to secure their tenure. Residents recognised the title deed as the primary proof of their ownership. Additional tenure information for them includes that their name is on the municipal account and the municipality has a record of their ownership. All the original beneficiaries and their heirs, who were asked directly what they would do if their tenure was challenged indicated that the title deed was their primary documentary evidence. They would use their deed when approaching one or more of the municipality, a lawyer, the police, and a local political party office for assistance (23 Interviews). They felt secure if they had a deed. Further supporting this finding, participant \#524 feared he might be evicted because he did not have his deed yet. 


\subsection{Registered Property Transactions}

Deeds office transfer records showed that 49 registered transactions involving 44 houses had occurred over ten years since first registration. Mirroring patterns in other case studies, key informants ventured that original beneficiaries in Project II sell because they move to another town, they want to buy another property, they divorce or separate, they owe too much municipal debt, or they want to move into the house of an elderly relative to provide care (Int. \#005, 449, 502, 505).

Most buyers identified a seller by word of mouth or cell phone advertisements through their social networks, or in an advertisement in the local newspaper (6 Interviews). The purchase price tended to be paid in cash, but sometimes the buyers would pay the seller in instalments (Int. \#152). Most of the participants were wary of mortgage bonds, a fear that can be ascribed to the uncertainty surrounding job security. They were unwilling to risk losing their house by using it to secure debt.

\subsection{Off-Register Transactions}

Residents referred to a number of uit die hand uit (by private agreement - Afrikaans), offregister transactions ( 7 interviews). These transactions are effected using oral agreements, private contracts, affidavits sworn by both parties at a police station, and handing over the title deed (15 interviews). In essence these are private conveyances or symbolic deliveries. A lawyer ventured that the importance assigned to the deed as an icon of property ownership, rather than the whole procedural legal arrangement of which it is a component, may influence this behaviour. That means handing over the deed is considered sufficient to complete the transaction (Int. \#152).

Evidence indicates that off-register transactions had been used when micro-lenders, gang lords, shebeen (informal bar) owners and poachers pressured beneficiaries, who owe them money, to hand over their house (Int. \#007, 499, 502). However this could not be investigated due to possible danger to interviewees and researchers and reluctance of the people involved to be interviewed.

Key-informants believed that off-register transactions are decreasing due to increasing knowledge of negative experiences of buyers and sellers who had used this strategy. These experiences included sellers reclaiming houses from buyers and buyers not paying the sellers the full purchase price after they had moved into the house (6 interviews). Participant \#505 claimed to have bought four different houses in 1999 using off-register transactions. The first transaction was by oral agreement. In the subsequent transactions he signed a private contract, his children witnessed the sale, and the title deed was exchanged. According to him all these houses were reclaimed by the sellers. In addition, the fourth seller sold the house to two different buyers by using a photocopy of the title deed to sell the house to a second buyer. Evidence to verify this story did not emerge. The participant may have concocted the story from hearsay or news items. It is also possible that he was involved in off-register transactions, perhaps as a micro-lender. 
The Yellow House was iconic in informing people about the risks of off-register transactions. When participants were asked about land tenure problems, a number of them mentioned the "Yellow House down the road". A husband and wife were the registered original beneficiaries. The wife's narrative, supported by key-informant and other resident interviews, was that her husband sold their house off-register for R5, 000. Consequently, they had to move out in 2003. The husband's employer then hired a lawyer and the matter went to court. A version of events is the court ruled that the sale was not in terms of the procedure required to effect registration. There was no documentary proof of a contract (contracts to sell land have to be in writing in South Africa). The court deemed the R5, 000 to be rent, and the original owners then moved in again (Int. \#507, 514, 519, 520, 529, 531). The buyer then returned and removed doors, windows and the roof of extensions to the house that he claimed to have built. He was then charged with trespassing and damage to property (Int. \#530).

\subsection{Transactions within the 5 years restriction period}

The restrictive clause has been identified as a cause of off-register sales, as people who are compelled to sell cannot do so without permission, and so they sell off-register. The seller then "disappears" and so registration cannot be completed when the restrictive period has passed as they are not on hand to sign the necessary documents. Key-informants indicated that in some cases, to ensure the title remains clean, lawyers allow the buyer and seller to enter into an agreement of sale before the end of the restrictive period, and the seller provides the lawyer with a Power of Attorney to sign the necessary documents for registration to proceed. Lawyers have not been found to do this in other case studies. Although not in the spirit of the objectives of the housing programme, the practice does ensure that the land records are current and accurate.

\section{Analysis and Conclusions}

Project II, Drakenstein-97 and Projects A \& B are, from an official perspective, arguably good news stories about registered transactions in state-subsidised housing in South Africa. It is important to ensure that studies of problem cases are balanced by studies that report what works and what can work with some minor interventions. Individual ownership was a given when these three housing projects were implemented. The environments were stable and people in the suburb had a history of renting houses, purchasing houses and instalment purchase systems prior to the state-subsidised housing programmes. They had experienced or observed different path-toownership processes. They favoured individual home ownership, they were aware of official land administration structures and processes, the considerable majority used them and intended to continue to use them. Thus there is a compelling argument that registered ownership works and can be made to work. Particularly noteworthy is that a desire to replace lawyers in the land transaction and estate management process did not surface in any of the cases. 
There are, however, issues that need to be addressed. Firstly, off-register sales do occur, and they cannot be wished away by merely making laws that forbid them. Secondly, there are some concerns about dead man's titles. Houses that are inherited through intestate succession may not be registered. The Yellow House case indicates that additional grassroots level support is required in providing advice, accessing legal assistance and financing the defence of tenure security. Management-by-walking-about, aka a role similar to that of building inspectors in checking that buildings comply with approved building plans or the survey technicians that deal with day to day land administration matters in some South African municipalities may reduce the incidence of offregister transactions. The questions, however, are who should do this, how it should be done without being perceived as paternalistic or interfering, and how might it be funded.

\section{Acknowledgements}

The support of the John Holmlund Chair in Land Tenure and Cadastral Systems is gratefully acknowledged.

\section{REFERENCES}

Barry M B 1999. Evaluating Cadastral systems in Periods of Uncertainty: A Study of Cape Town's Xhosaspeaking Communities. PhD thesis, University of Natal, Durban.

Barry M 2006. Formalising Informal Land Rights: the case of Marconi Beam and Joe Slovo Park. Habitat International. 30(2006), $628-644$.

Barry M and Roux L 2012. A Change Based Framework for Theory Building in Land Tenure Information Systems, Survey Review, 44 (327) 301- 314.

Barry M and Roux L 2013. The Case Study Method in Examining Land Registration Usage. Geomatica. 67(1), $267-281$.

Barry M and Roux L 2014. Perceptions of Land Registration in a state-subsidised housing project in South Africa. Housing Finance International, XXVIII (4), 27 -33.

Barry M and Danso E 2014. Tenure Security, Land Registration and Customary Tenure in Peri-urban Accra: A Case Study. Land Use Policy. 39 (2014), 358-365.

Barry M. 2015. Property Theory, Metaphors and the Continuum of Land Rights, UN-Habitat / Global Land Tools Network, Nairobi. http://www.ucalgary.ca/mikebarry/files/mikebarry/barry-2015-propertytheory-metaphors-and-the-continuum-of-land-rights-published.pdf

Barry M and Roux L 2016. Land Ownership and Land Registration Suitability Theory in State-Subsidised Housing in a Rural South African Town, Habitat International, 53, April 2016, 48 - 54.

Department of Human Settlements 2014. Delivery of Serviced Sites / Units from the HSDG since 1994 Ver 29052015.

http://www.dhs.gov.za/sites/default/files/documents/statistics/20\%20Year\%20delivery\%20Sites\%20 $\% 26 \% 20$ Houses\%20HSDG\%20finalised\%20ver.\%2029052014.pdf [2015.09.14].

Downie L 2011. Urban Pro-Poor Registrations: Complex-Simple The Overstrand Project. Potchefstroom Electronic Law Journal (PER), 14(3), 119- 160.

Financial and Fiscal Commission 2012. Building an Inclusionary Housing market: Shifting the Paradigm for South Africa. Report on the Public Hearings on Housing Finance. 31 January 2012. 
South African Journal of Geomatics, Vol. 5, No. 1, February 2016

Gordon R, Nell M and di Lollo A 2011. Investigation into the delays in issuing Title Deeds to Beneficiaries of Housing Projects funded by the capital subsidy. Urban Landmark.

Greene O 1994. A Breakdown of the South African Land Tenure System. South African Journal of Surveying and Mapping, 22(4) $250-252$.

Kingwill R. 2013. The map is not the territory: law and custom in 'African freehold': a South African case study, PhD Thesis, University of the Western Cape.

McLaren, R. (2011). Crowdsourcing Support of Land Administration. Royal Institute of Chartered Surveyors.

Roux L M 2013. Land Information Systems and User Behaviour: Examining land transactions in social housing estates in South Africa. PhD thesis, University of Calgary.

Shipton P 2009. Mortgaging the Ancestors. Ideologies of Attachment in Africa, Yale University Press, New Haven

UN-Habitat/GLTN 2012. Handling Land. Innovative tools for land governance and secure tenure. Available at: http://www.unhabitat.org. [Accessed 2014.05.26]

Vorster, J.H. and J.E. Tolkien 2008. Western Cape occupancy study 2008. Western Cape

Department of Local Government and Housing, Cape Town. 